RACAR : Revue d'art canadienne

Canadian Art Review

RACAR

\title{
Vincent Van Gogh's Magical Concept of Portraiture and Paul Gauguin's Bonjour M. Gauguin
}

\section{Vojteck Jirat-Wasiutynski}

Volume 3, numéro 1, 1976

URI : https://id.erudit.org/iderudit/1077382ar

DOI : https://doi.org/10.7202/1077382ar

Aller au sommaire du numéro

Éditeur(s)

UAAC-AAUC (University Art Association of Canada | Association d'art des universités du Canada)

\section{ISSN}

0315-9906 (imprimé)

1918-4778 (numérique)

Découvrir la revue

Citer cette note

Jirat-Wasiutynski, V. (1976). Vincent Van Gogh's Magical Concept of Portraiture and Paul Gauguin's Bonjour M. Gauguin. RACAR : Revue d'art canadienne / Canadian Art Review, 3(1), 65-67. https://doi.org/10.7202/1077382ar

Tous droits réservés (C) UAAC-AAUC (University Art Association of Canada | Association d'art des universités du Canada), 1976
Ce document est protégé par la loi sur le droit d'auteur. L’utilisation des services d'Érudit (y compris la reproduction) est assujettie à sa politique d'utilisation que vous pouvez consulter en ligne.

https://apropos.erudit.org/fr/usagers/politique-dutilisation/ 


\section{Vincent Van Gogh's Magical Concept of Portraiture and Paul Gauguin's Bonjour M. Gauguin*}

Gauguin's self-portraits are not portraits in the traditional sense of the word, but rather images through which he tried to identify aspects of his character and forge a new personality for himself. Vincent Van Gogh held a similar view on the close relationship between portrait and personality; in describing his Self-Portrait as a Bonze Vincent had written that he would have to develop his personality further in order to have a "better model for a better painting".' It was most probably through direct discussion in Arles that Gauguin shaped his conception of the symbolist portrait.

Vincent's attention had become focused almost exclusively on portraiture in the autumn of 1888 . When he visited the Bruyas Gallery at Montpellier with Gauguin in December, their discussion seems to have centred on the portrait: a letter to Theo reflects the conversation. It must have begun in front of Delacroix's Portrait of Bruyas. "Brias [sic] was a benefactor of artists. I need say no more to you than that. In the portrait by Delacroix he is a gentleman with red beard and hair like you or me, and made me think of that poem by de Musset 'Partout où j'ai touché la terre -- un malheureux vêtu de noir, auprès de nous venait s'asseoir, qui nous regardait comme un frère'." " Vincent repeated the idea at the end of the letter, affirming a spiritual brotherhood of artists, patrons, and amateurs based on common bonds of suffering and sympathy. "Tell Degas that Gauguin and I have been to see the portrait of Brias [ sic] by Delacroix

\footnotetext{
* The following article has been excerpted from Gauguin in the Context of Symbolism, a doctoral dissertation submitted to the Department of Art and Archaeology, Princeton University, in May 1975.
}

' The Complete Letlers of Vincent Van Gogh, London. Thames \& Hudson, 1958, III, 64, no. 544a (ca. October 1, 1888).

\footnotetext{
2 Ibid., III, 108, no. 564 (December 1888): the black figure, as a consoling sister, had turned up earlier in the 1876 Sermon quoted below. For the precise dating of Van Gogh's letters of October - December 1888 see Mark Roskill, Van Gogh, Gauguin and the Impressionist Circle. New York Graphic Society, Greenwich, Conn., 1970, 274-7.
}

at Montpellier, for we have the courage to believe that what is is, and the portrait of Brias [sic] by Delacroix is as like you and me as another brother." ${ }^{3}$ The emphasis on "what is is" translates some of the mystical, almost deranged fervour with which Vincent must have told Gauguin these things.

To the concept of a spiritual brotherhood, Vincent Van Gogh then linked the idea of the artist as a "Traveller" or "Man Come from Afir"; the notion was undoubtedly discussed in front of Courbet's Bonjour Monsieur Courbet, although only Rembrandt was mentioned in the letter. "You know the strange and malgnificent Portrait of a Man by Rembrandt in the Lacaze Gallery. I said to Gauguin that I myself silw in it a certain family or racial resemblance to Delacroix or to Gauguin as well. I do not know why, but I alwalys call this portrait 'The Traveller' or 'The Man Come from Afar'." Vincent had discussed the image of the traveller once before in his sole preserved sermon of 1876. The sermon was on the text of Psalm 119. verse 19: "I am a stranger on earth, hide not Thy commandments from me." Vincent concentrated on the image of the "pilgrim"s progress", which he illustrated by reference to a painting of that subject.

It is an old belief and it is a good belief, that our life is a pilgrim's progress - that we are strangers on the earth...

We are pilgrims on the earth and strangers -we come from afar and we are going far - the journey of our life goes from the loving breast of our Mother on earth to the arms of our Father in heaven...

${ }^{3}$ The Complete Letlers, III, 109.

Ibid. The Lacaze Gallery was in the Louvre and contained the Lacaze Bequest: see Paris, Louvre, Notice des Tahleaur légués au Musée Impérial du Louvre par M. Louis Lacaze, 1870. no. 98, "Portrait d'Homme ". Mark Roskill has pointed out to me that Vincent must have been referring to the work presently known as L'Homme au Bälon (fig. 1). 


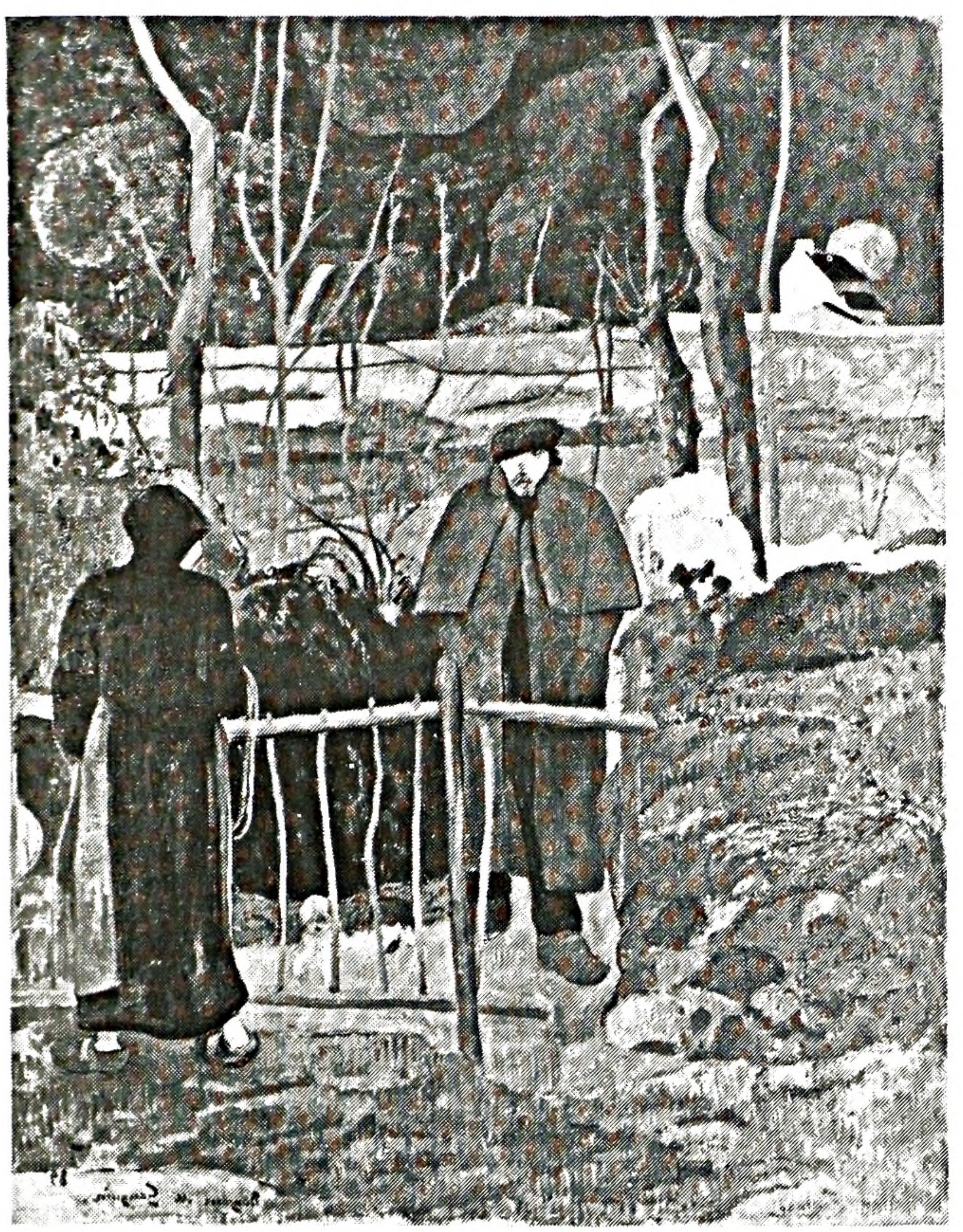

Figure 1. Paul Gauguin, Bonjour Monsieur Gauguin. Prague, National Gallery.

Our life is a pilgrim's progress. I once saw a very beautiful picture: it was a landscape at evening... Through the landscape a road leads to a high mountain; far, far awaly, on the top of that mountain is al city whereon the setting sun casts a glory. On the road walks a pilgrim, staff in hand. He has been walking for a good long while already and he is very tired. And now he meets a woman, or figure in black... That angel of God has been placed there to encourage the pilgrims...

Let us not forget... that our life is a pilgrim's progress, and that we are strangers on the earth $\ldots$ and that we are all brethren. ${ }^{s}$

\footnotetext{
s The Complete Letters, I, 87 and 90-91; he had described the painting to Theo in a letter of 26 August $1876(66$, no. 74). where he identified the painter as Boughton. The painting by George Henry Boughton has recently been identified by Ronald Pickvance in the exhibition catalogue English Influences on Vincent Van Gogh. Fine Art Department, University of Nottingham and the Arts Council of Great Britain, 1974-5. 23, as God Speed! Pilgrims selting out for Canterbury: Time of Chaucer (Royal Academy Exhibition, 1874, no. 982), although no reproduction has yet been traced. If this identification is correct, then Vincent confused the image with Bunyan's "pilgrim's progress," and in his 1876 sermon remembered only two figures where there had been more.
}

Vincent seems to have retained this idea, although it was transformed in terms of humanitarian socialism after his loss of faith.

It was the duty of human beings to help each other, since they were all brethren during their sojourn on earth. For the religious concept of "life after death", Vincent Van Gogh substituted a secular ideal of cultural immortality: all human beings, and particularly the artists, participated in the development of humanity and thereby partook of a certain "life after death". In a letter of late March - early April 1888. Vincent quoted a poem, as follows: "O never think the dead are dead, / So long as there are men alive, / The dead will live. the dead will live." He did so in connection with the news of Anton Mauve's death, which he had just received. "Something - I don't know what took hold of me and brought a lump to my throat. and I wrote on my picture 'Souvenir de Maluve. Vincent Theo'... I chose the best study I've painted here purposely..." Confronted with death, Vincent immediately affirmed his belief in the spiritual continuity, i.e. secular immortality. of the artistic tradition.

Vincent did not, however, reject the religious concept of immortality entirely: he simply put a question mark behind the phrase. In a letter of August 1888, he wrote to Theo that "I always feel that I am a traveller. going somewhere and to some destination. If I tell myself that the somew here and the destination do not exist, that seems to me very reasonable and likely enough."

The sight of Courbet's Bonjour Monsieur Courbet, in which the wandering artist ${ }^{8}$ is greeted by his patron, must have brought both the imagery of the "traveller from afar" and the concept of the spiritual brotherhood of artists. patrons and collectors to Vincent's mind. He probably explained these ideas to Gauguin, further illustrating them with the example of Rembrandi's portraiture which he mentioned in the letter to Theo. Moreover, he had reminded Theo that this notion of the "family or racial resemblance" of artists and patrons was "similar and parallel to the one l've already spoken to you about, namely that I always see your future self in the portrait of old Six, the fine portrait of the Man with the Glove, and in Rembrandt's etch-

"Ibid.. II, 537-8, no. 472 (March-April 1888).

'Ibid., III, 2, no. 518 (August 1888).

${ }^{8}$ The picture relates to the tradition of the wandering Jew and the Socialist preachers like Jean Jouvenet: see Linda Nochlin, "Gustave Courbet's Meeting. a Portrait of the Artist as a Wandering Jew", Arl Bulletin, CIX, 1967, 209-222. 
ing Six Reading near a Window in a Shaft of Sunlight yourself in the past and present." Vincent's view of portraiture was almost magical: ${ }^{10}$ since the spiritual kinship of the sitters transcended time, a portrait could reveal the future appearance of another sitter when he reached a comparable age. The magic identification between portrait and sitter is akin to the famous instance in Oscar Wilde's Portrait of Dorian Gray." "

Gauguin's self-portraits of 1889 , such as the Self-Portrait with Halo and Snate in the National Gallery, Washington (W323), ${ }^{2}$ show a very close personal identification of image and artist with an almost magical belief in their power to transform reality. In addition, one of them reveills a specific relationship to Vincent's concept of the "Traveller" and to the Rembrandt Portrait of a Man (fig. 1).

"Bonjour M. Gauguin" (W322), now in the National Gallery. Prague (fig. 2), shows Gauguin, carrying a switch, approaching a gate in the countryside near Le Pouldu. The vegetation is coloured an acid yellow-green and bare, gnarled tree trunks dominate the foreground; the sky is a deep blue with storm clouds coming. Gauguin strides toward us, wrapped in his great coat, his beret pulled over one eye. while the other eye is hooded as he looks down; his pinched, pale face betrays a desperate, lonely man. To the right, on the other side of the barrier, a Breton peasant wom an moves away from Gauguin while appearing to look at him. The painting is quite clearly a counterpart to Courbet's Bonjour Monsieur Courbet (1854), ${ }^{13}$ which Gauguin had seen just recently and probably discussed with Vincent. Gauguin was certainly aware of Vincent's imagery of the "traveller", since in December 1888 he had written to Schuffenecker

* The Complete Lellers, II, 109, no. 564 (ca. December 20. 1888); see also 11. 576, no. 492 (May 29. 188). The works by Rembrandt can be found in A. Bredius, Rembrandr. The Complete Edition of the Painlings, revised by $\mathrm{H}$. Gerson, London, Phaidon. 1969. 211; and in Hollstein's Dutch and Flemish Elchings. Engravings and Woodculs, XIX (Rembrandı van Rijn), Plate 241 (Bartsch 285).

10."We were in the midst of magic, for as Fromentin says so well: Rembrandt is above all a magician." (The Complete Letters, III, 109, no. 564 ca. December 20, 1888.)

"See Mario Praz, The Romantic Agony, Cleveland, Meridian, 1967, 344.

12 Georges Wildenstein and Raymond Cogniat, Gauguin, Catalogue, I, Paris, Les Beaux-Arts. 1964, no. 323; henceforth referred to by "W" followed by a catalogue number.

${ }^{13}$ T. Brunius, "Inside and Outside the Frame of a Work of Art", in Idea and Form. Figura, n.s. 1, 1959. 1-23, discussed the relationship.

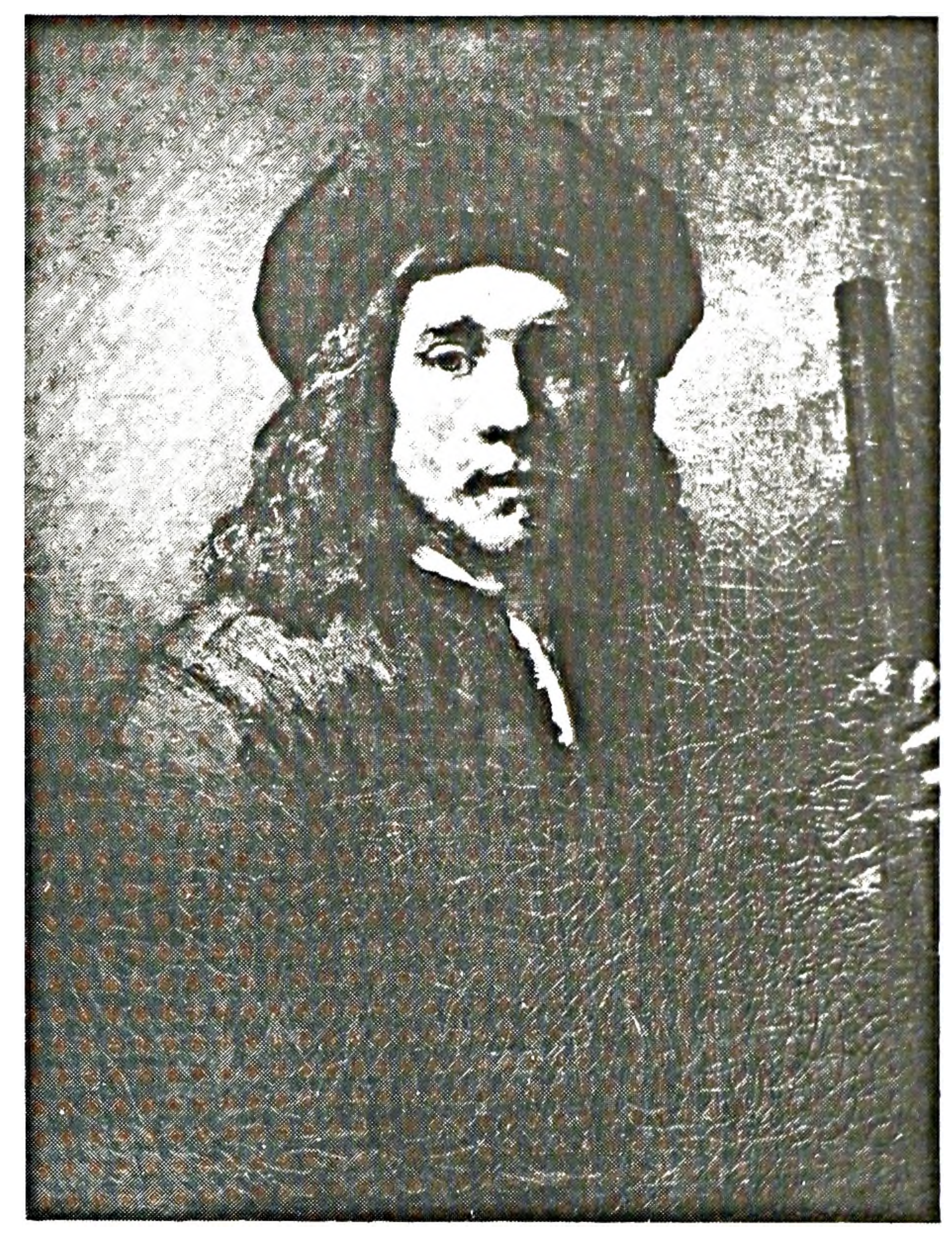

Figure 2. Rembraudt, L'homme au bâton. Paris, Louvre.

that "Vincent m'appelle quelquelois l'homme qui vient de loin et qui ira loin". "But, where Courbet's work reveals an artist welcomed and greeted by his patron in a sunny southern landscape, Gauguin showed himself alone, except for a bretonne who avoids him, in a sombre landscape menaced by a storm. ${ }^{15}$ The image reflects Gauguin's sense of abandonment in October and November 1889 at Le Pouldu and corresponds to his contemporary Self-Portrait in Gethsemane (W326). ${ }^{16}$

Vojteck Jirat-Wasiutynski Queen's University' Kingston

\footnotetext{
1t Letter, December 1888, in A. Alexandre, Gauguin, Paris Bernheim Jeune, 1930, 94: it is in this letter that he refers to himself as an Inca come from the sun. In this connection it is interesting to note that Gauguin's favourite childhood painting was a Merry Wayfarer, an engriving after which hung in his mother's house (Pola Gauguin, My Father, Paul Gauguin. New York, Knopf, 1937, 15).

\begin{abstract}
is See the reduced version of the same subject (W321), which
\end{abstract} was stuck to the door of Marie Henry's inn at Le Pouldu (Charles Chassé, Gauguin el son temps. Paris. Bibliothèque des Arts, $1955,74)$. Here the bretonne appears striding toward Gauguin, as if to welcome him, or at least open the gates, and the sky is not cloudy: a more appropriate sentiment for the inn where he enjoyed hospitality.

${ }^{16}$ See Leltres de Gauguin à sa femme el à ses amis. éd. Maurice Malingue, Paris, Grasset, 1949, 173-6, no. XCII (November 1889). In letter no. XC (October 1889), Gauguin referred to his desire to study Rembrandt more closely.
} 